\title{
KETAMINE WITH PANCURONIUM FOR INDUCTION OF ANAESTHESIA
}

\author{
J.W.R. McINTYRE, F.R.C.P. (c), D. Dobson, F.R.C.P. (c), \\ AND G. AITKEN, D.A., M.B., CH.B.
}

KeTAMINE AND PANCURONIUM are relatively new agents each of which has been described as valuable for anaesthesia in poor-risk patients. The fact that one of them is a general anaesthetic and the other a muscle relaxant suitable for intubation suggests that the sequential or combined use of these drugs might be considered as a technique for induction of anaesthesia. This possibility was examined during routine clinical anaesthesia in the following manner:

One group consisting of ten healthy adult patients was premedicated with morphine $10 \mathrm{mg}$ and hyoscine $0.4 \mathrm{mg}$. Anaesthesia was induced either with pancuronium $0.1 \mathrm{mg} / \mathrm{kg}$ followed by thiopentone $5 \mathrm{mg} / \mathrm{kg}$ over a period of 60 seconds, or with pancuronium $0.1 \mathrm{mg} / \mathrm{kg}$ followed by ketamine $2 \mathrm{mg} / \mathrm{kg}$ again over 60 seconds. The lungs of these patients were artificially ventilated with nitrous oxide and oxygen during the succeeding two minutes and the trachea was then intubated. The blood pressure was measured by sphygmomanometry and written records of the electrocardiograph were made. The findings are shown in Table I. The increase in pulse rate was similar in both groups. The patient who had received ketamine had an increase in both systolic and diastolic pressure. Those who had received thiopentone showed a decrease in systolic pressure. There were no cardiac irregularities in either group.

The next group of patients was dealt with in a similar manner except that the ketamine or the thiopentone preceded the pancuronium. The findings appear in Table II and are similar to the previous group.

Commercial preparations of ketamine and pancuronium are miscible and consequently in yet another group of ten healthy adult patients ketamine $2 \mathrm{mg} / \mathrm{kg}$ and pancuronium $0.1 \mathrm{mg} / \mathrm{kg}$ were mixed in the same syringe, the total volume of solution varying from 20 to $25 \mathrm{ml}$ and the whole was injected intravenously over a period of 60 seconds. The changes produced were similar to those observed when the drugs were given sequentially.

Finally in Table III are shown the results of injecting a mixture of ketamine $2 \mathrm{mg} / \mathrm{kg}$ and pancuronium $0.1 \mathrm{mg} / \mathrm{kg}$ over 60 seconds or pancuronium $0.1 \mathrm{mg} / \mathrm{kg}$ followed by thiopentone $3 \mathrm{mg} / \mathrm{kg}$ over the same sixty-second period into patients about to undergo coronary artery bypass procedures. Systemic blood pressures were recorded from intra-arterial catheters. A slight increase was seen in the pulse rate of those patients who had received ketamine and there was an increase in systemic blood pressure. No cardiac arrhythmias occurred; however, there was a marked response to tracheal intubation in both groups. This same drug combination was administered to two patients for mitral valve replacement. The results

- Department of Anaesthesia, University Hospital, Edmonton, Alberta. 


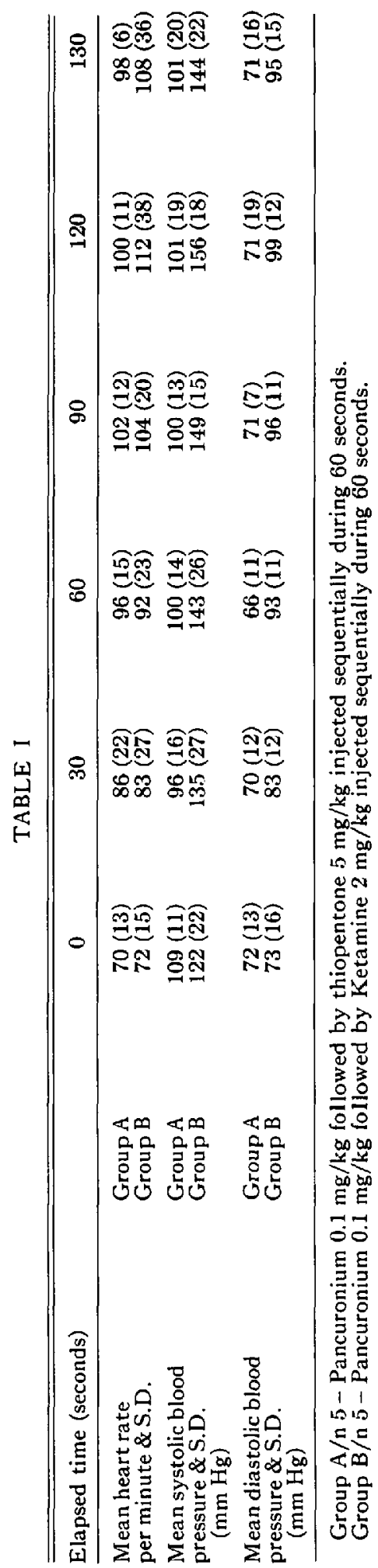


TABLE II

\begin{tabular}{lccccc}
\hline \hline Elapsed time (seconds) & & 0 & 60 & 120 & 180 \\
\hline Mean heart rate & Group A & $70(8)$ & $93(8)$ & $90(8)$ & $86(6)$ \\
per minute \& S.D. & Group B & $74(16)$ & $91(14)$ & $99(19)$ & $103(26)$ \\
$\begin{array}{l}\text { Mean systolic blood } \\
\text { pressure \& S. D. }\end{array}$ & Group A & $124(10)$ & $106(20)$ & $104(11)$ & $108(20)$ \\
$\quad$ (mm Hg) & Group B & $131(16)$ & $151(43)$ & $174(47)$ & $178(49)$ \\
$\begin{array}{l}\text { Mean diastolic } \\
\text { blood pressure \& S.D. }\end{array}$ & Group A & $81(8)$ & $80(17)$ & $79(12)$ & $81(11)$ \\
$\quad$ (mm Hg) & Group B & $79(7)$ & $90(12)$ & $96(15)$ & $100(19)$ \\
\hline
\end{tabular}

Group A/n 5 - Thiopentone $5 \mathrm{mg} / \mathrm{kg}$ followed by pancuronium $0.1 \mathrm{mg} / \mathrm{kg}$ injected sequentially during 60 seconds

Group $\mathrm{B} / \mathrm{n} 5$-Ketamine $2 \mathrm{mg} / \mathrm{kg}$ lollowed by pancuronium $0.1 \mathrm{mg} / \mathrm{kg}$ was administered intravenously during 60 seconds

were similar to those described for previous cases but a marked tachycardia developed (Table IV).

In summary, the administration of ketamine $2 \mathrm{mg} / \mathrm{kg}$ and pancuronium 0.1 $\mathrm{mg} / \mathrm{kg}$ simultaneously or sequentially was associated with an increase in pulse rate, systolic and diastolic arterial pressures of widely varying magnitude. Cardiac arrhythmias did not occur, even in association with the sudden increases in blood pressure which commonly occurred in association with tracheal intubation.

In discussing these findings it is clear that they represent only rudimentary information necessary for the selection of an induction technique for poor risk cases, and that they must be considered together with other available information.

The intravenous induction dose of ketamine recommended in man is approximately $2 \mathrm{mg} / \mathrm{kg}$ injected over 15 to 60 seconds. It has been studied both in healthy subjects and in patients with cardiovascular disease. ${ }^{1-5}$ Information from these studies is summarized in Table V. The mechanism by which these cardiovascular effects are produced has not been completely elucidated, but apparently they are due to an interaction between direct vascular effects, direct myocardial effects, modification of baroreceptor responses, central autonomic effects, and environmental sensory input. ${ }^{4-7}$ The effects of pancuronium on the cardiovascular system $^{8-12}$ are summarized in Table VI. However, these changes should not be anticipated in every case. Animal experiments and clinical findings indicate that the cardiovascular effects of pancuronium are largely due to its vagolytic action. ${ }^{11,13}$ The heart rate prior to its administration provides a clue to the drug's ultimate effect, ${ }^{14}$ although this cannot be predicted with certainty. From the foregoing it appears likely that the addition of pancuronium might have two principal effects on the cardiovascular effects of ketamine: the reflex cardiovascular effects of increased muscle tone would be attenuated and the vagolytic effects would be augmented. Considering the multitude of factors influencing the effects of these drugs, a large variation in the magnitude of changes produced could be expected and the responses reported here indicate that such is the case.

Reports have described the successful use of ketamine for the investigation of patients and for operation on those with a variety of cardiac problems $s^{1,2,4,15,16}$ and in other difficult clinical situations. ${ }^{1 \top}$ However, it should be realized that central 


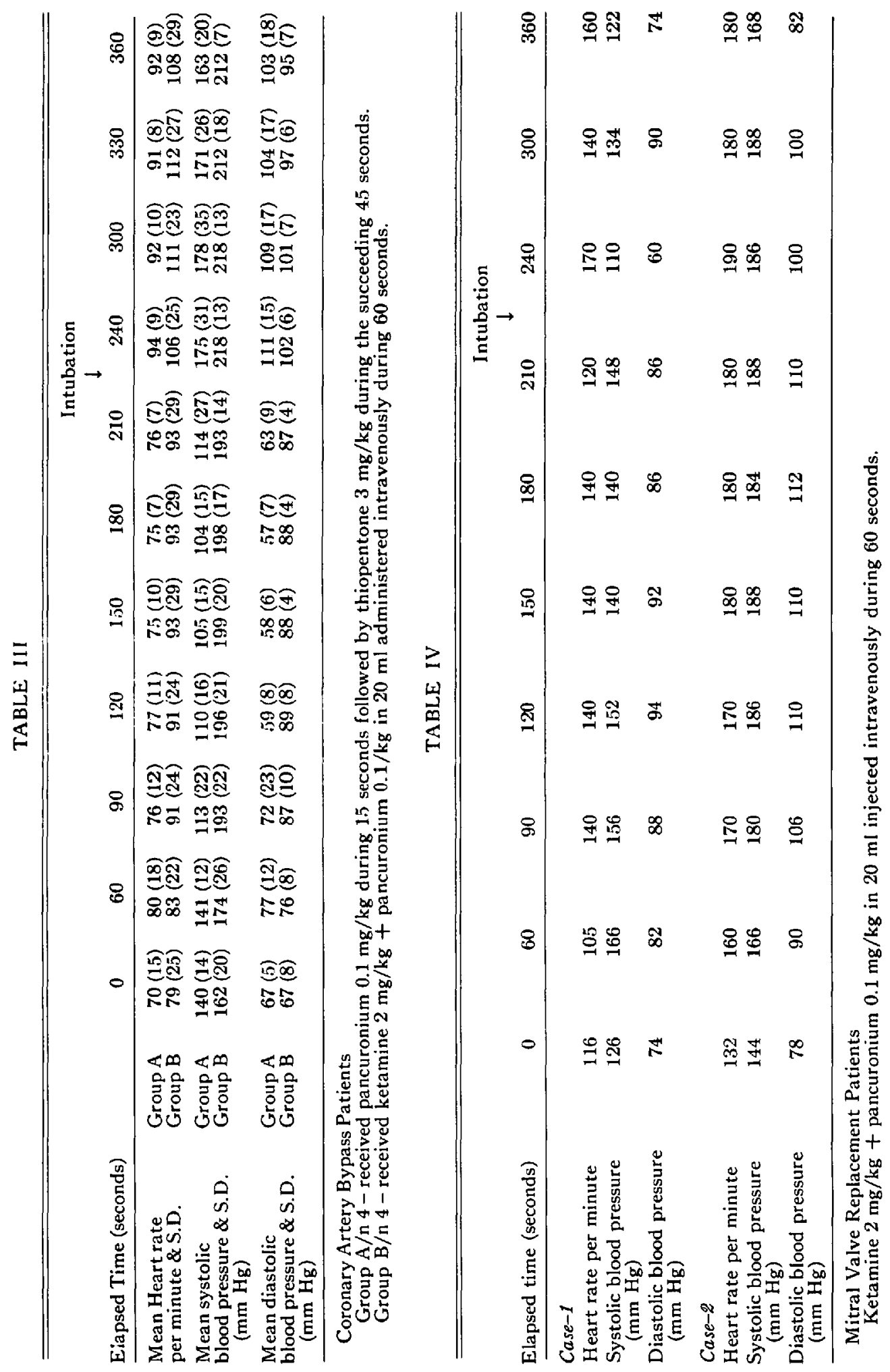


MCINTYRE, et al.: KETAMINE PLUS PANCURONIUM

TABLE $V$

Effects of Ketamine on The Cardiovascular System

\begin{tabular}{lccccc}
\hline \hline & $\begin{array}{c}\text { Tweed } \\
1972\end{array}$ & $\begin{array}{c}\text { Coppel } \\
1972\end{array}$ & $\begin{array}{c}\text { Bovill } \\
1972\end{array}$ & $\begin{array}{c}\text { Stanley } \\
1968\end{array}$ & $\begin{array}{c}\text { Savage } \\
1973\end{array}$ \\
\hline $\begin{array}{l}\text { Systemic B.P. } \\
\begin{array}{l}\text { Systemic vascular } \\
\text { resistance }\end{array}\end{array}$ & $\uparrow$ & $\uparrow$ & $\uparrow$ & $\uparrow$ & $\uparrow$ \\
$\begin{array}{l}\text { C.V.P. } \\
\text { Heart rate }\end{array}$ & $\uparrow$ & $\uparrow$ & $\uparrow$ & $\uparrow$ & $\uparrow$ \\
$\begin{array}{l}\text { Cardiac output } \\
\text { Cardiac index }\end{array}$ & $\uparrow$ & & & & $\uparrow$ \\
$\begin{array}{l}\text { Stroke volume } \\
\begin{array}{l}\text { Myocardial } \\
\text { contractility }\end{array}\end{array}$ & $\uparrow$ & & & & $\uparrow$ \\
$\begin{array}{l}\text { Myocardial } \mathrm{O}_{2} \\
\text { requirements }\end{array}$ & $\uparrow$ & & & & \\
$\begin{array}{c}\text { Pulmonary artery } \\
\text { pressure }\end{array}$ & $\uparrow$ & $\uparrow$ & & & \\
\hline
\end{tabular}

TABLE VI

Effects of Pancuronium on the Cardiovascular System

\begin{tabular}{lccccc}
\hline \hline & $\begin{array}{c}\text { Staelting } \\
1972\end{array}$ & $\begin{array}{c}\text { Coleman } \\
1972\end{array}$ & $\begin{array}{c}\text { Kelman } \\
1971\end{array}$ & $\begin{array}{c}\text { Lubke } \\
1971\end{array}$ & $\begin{array}{c}\text { Gertal } \\
1972\end{array}$ \\
\hline Heart rate & $\uparrow$ & $\uparrow$ & $\uparrow$ & $\uparrow$ & $\uparrow$ \\
$\begin{array}{l}\text { Mean arterial } \\
\text { blood pressure }\end{array}$ & $\uparrow$ & $\uparrow$ & $\uparrow$ & & $\uparrow$ \\
Cardiac output & $\uparrow$ & $\uparrow$ & $\uparrow$ & & $\uparrow$ \\
Stroke volume & & & & $\uparrow$ & $\uparrow 1-$ \\
$\begin{array}{l}\text { Systemic vascular } \\
\text { resistance }\end{array}$ & & $\uparrow$ & & & $\uparrow /-$ \\
Mean C.V.P. & & & & $\uparrow$ & $\downarrow$ \\
Cardiac force & & & & $\uparrow$ & \\
Cardiac power & & & & & \\
\hline
\end{tabular}

depressant agents which modify the effects of the drug have been present. Pancuronium has received wide acceptance as a drug useful in the management of many poor risk patients. Thus these drugs have an established place in the practice of anaesthesia. It is with their rapid sequential or combined administration for the induction of anaesthesia that we are concerned here. There are no other such reports available except a comment that two of three patients in whom anaesthesia had been induced with ketamine developed a hypertensive response following the subsequent administration of pancuronium. ${ }^{18}$ It is our opinion that, used alone in the manner described here, this is a potentially dangerous combination for some patients. Only careful assessment of each patient in the light of his cardiovascular problem, be it mitral stenosis or hypovolaemic shock, and of such other drugs which have been or will be administered, can allow a rational 
decision to be made regarding the use of this combination for the induction of anaesthesia.

\section{SUMMARY}

Ketamine and pancuronium have been administered intravenously either in rapid sequence or mixed together for the induction of anaesthesia. The subjects were either healthy patients or those suffering from coronary artery disease or mitral stenosis. Changes in blood pressure and pulse rate were variable, a marked tachycardia occurring in some patients. The opinion is expressed that this combination of drugs is potentially dangerous for some patients. Only a careful assessment of each patient in the light of the cardiovascular problem and such other drugs as have been or will be administered, can enable a rational decision to be made regarding the use of this technique for the induction of anaesthesia.

\section{RÉSUMÉ}

Chez deux groupes de malades, les uns en bonne santé, les autres souffrant d'insuffisance coronarienne ou de sténose mitrale, nous avons effectué l'induction de l'anesthésie avec de la Kétamine et du Pancuronium intra-veineux, soit en solution pré-mélangée ou en injections séquentielles rapides.

Les changements du pouls et de la pression artérielle furent variables avec occasionnellement une tachycardie marquée chez certains malades. Nous sommes d'opinion que cette association médicamenteuse est potentiellement dangereuse dans certains cas. C'est seulement à la suite d'une évaluation attentive de chaque malade, de son état cardio-vasculaire et des médicaments qu'il a reçus ou recevra, qu'on décidera d'une façon éclairée de l'indication d'une telle méthode d'induction.

\section{REFERENCES}

1. Stanley, V., Hunt, J., Willis, K.N., \& Stephen, C.R. Cardiovascular and respiratory function with CI-581. Anesth. \& Analg. 47: 760 (1968).

2. Coppel, C.L. \& Dundee, J.W. Ketamine anaesthesia for cardiac catheterization. Anaesthesia 27: 25 (1972).

3. Bovill, J.G. \& DundeE, J.W. Attempts to control the cardio stimulatory effect of ketamine. Anaesthesia 27: 309 (1972).

4. Tweed, W.A., Minuck, M., \& Mymin, D. Circulatory responses to ketamine anesthesia. Anesthesiology 37:613 (1972).

5. Savece, T.M., Blogg, C.E., Foley, E.J., Ross, L., Lang, M., \& Simpson, B.R. The cardiorespiratory effects of Althesin and Ketamins. Anaesthesia 28: 391 (1973).

6. Traber, D.L., Wilson, R.D., \& Prano, L.L. The effect of alpha-adrenergic blockade on the cardiopulmonary response to ketamine. Anesth. \& Analg. 50:737 (1971).

7. Chodoff, P. Evidence for central adrenergic action of ketamine. Anesth. \& Analg. 51: 247 (1972).

8. Lobke, P. \& Dannmann, H.J. Uber den einfluz von pancuronium bromide auf das herz Kreislaufverhalten in Neuroleptanalgesie. Anesthetist 20: 402 (1971).

9. Kelman, G.R. \& Kennedy, B.R. Cardiovascular effects of pancuronium in man. Brit. J. Anaesth. 43: 335 (1971).

10. Gertel, M., Fox, G.S., Rabow, F., \& Graham, D.H. The cardiovascular effects of pancuronium bromide during halothane anaesthesia. Can. Anaesth. Soc. J. 19: 599 (1972). 
11. Coleman, A.J., Downing, J.W., Leary, W.P., Moyes, D.G., \& Styles, M. The immediate cardiovascular effects of pancuronium, alcuronium and tubocurarine in man. Anaesthesia 27: 415 ( 1972).

12. Stoelting, R.K. The hemodynamic effects of pancuronium and d-tubocurarine in anaesthetized patients. Anesthesiology 36:612 (1972).

13. Saxena, P.R. \& Bonta, I.L. Specific blockade of cardiac muscarinic receptors by pancuronium bromide. Arch Int. Pharmaco. Therap. 189: 410 (1971).

14. McIntYre, J.W.R. \& GaIN, E.A. Initial experience during the clinical use of pancuronium bromide. Anesth. \& Analg. 50: 813 (1971).

15. Sanchez, R., Canseco, J.L.T., Acuna, L., \& Mireles, M. The use of ketamine on patients undergoing cardiac surgery. Anesthetist 20: 152 (1971).

16. Conssen, G. Ketamine for high risk cardiac patients. Anesthesiology 36: 413 (1972).

17. Dillon, J.B. Ketamine. Proc. Roy. Soc. Med. 64: 1153 ( 1971 ).

18. Lorhan, P.H. \& LippmanN, M. Clinical appraisal of pancuronium bromide for the aged patient. Anesth. \& Analg. 51 : 914 (1972). 